\title{
Indigenous Knowledge Systems and Indicators of Rain: Evidence from Rwenzori Region, Western Uganda ${ }^{\mathscr{O}}$
}

\author{
Michael Robert Nkuba, Raban Chanda, and Gagoitseope Mmopelwa \\ Department of Environmental Sciences, University of Botswana, Gaborone, Botswana \\ MARGARET NAJJINGO MANGHENI \\ Department of Extension and Innovation Studies, College of Agricultural and Environmental Sciences, \\ Makerere University, Kampala, Uganda \\ DAVID LESOLLE \\ Department of Environmental Sciences, University of Botswana, Gaborone, Botswana \\ EDWARD KATO \\ International Food Policy and Research Institute, Washington, D.C.
}

(Manuscript received 12 February 2019, in final form 21 November 2019)

\begin{abstract}
This study investigated the abiotic and biotic environmental indicators used among pastoralists and arable farmers to predict the onset and cessation of rain as well as to make short-term and seasonal forecasts in the Rwenzori region of Western Uganda. We used a mixed-methods approach that included surveys of 907 households, focus group discussions, and key informant interviews. The results indicate that resident birds such as white-browed coucals and turacos and migrant birds such as eagles and swallows were important indicators of the onset of rains. Butterflies were an important indicator for the cessation of rains, and red ants were an indicator for the onset of rains. Among the abiotic indicators, winds, clouds, earthquakes, and cloud formation on Mount Rwenzori were important indicators. Behavior of cattle at the onset of rains was important among the pastoralists, and flowering of coffee plants was important among the arable farmers. The behavior of the biotic indicators was driven by the availability of food, water, or other necessities. An attempt to explain the phenology underlying the behavior of biotic indicators and the meteorological science underlying some of the abiotic indicators is made. Although biotic environmental indicators are rudimentary and their accuracy is influenced by external factors such as climate change, they provide climate information within the locality of the farmers. Our results suggest that the indicators used in indigenous forecasting could be incorporated in national meteorological systems in a bid to improve the accuracy of rainfall forecasts and their use among farmers and pastoralists in rural Africa.
\end{abstract}

\section{Introduction}

Despite the increase in dissemination of scientific forecasts (SF) through radio and television stations and the Internet, indigenous forecasts (IF) are still

Supplemental information related to this paper is available at the Journals Online website: https://doi.org/10.1175/WCASD-19-0027.s1.

Corresponding author: Michael Robert Nkuba, mnkuba@ gmail.com commonly used in rural areas of the developing world, including Africa, where indigenous knowledge systems are part and parcel of rural communities (HoeghGuldberg et al. 2018). An indigenous knowledge system (IKS) has been defined as "a cumulative body of knowledge, practice and belief, working by adaptive processes and handed down through generations by cultural transmission, about the relationships of living beings (including humans) with one another and with their environment" (Berkes 1999, p. 8). This implies that IKS has the temporal dimension of passage from one generation to another and the spatial dimension 
concerned with aspects that happen in a given locality. There are various aspects of IKS, and indigenous knowledge forecasting (IKF) will be the central theme for this paper.

The use of IKF in Uganda and elsewhere has been reported in the literature (Roy et al. 2018), but locally specific indicators have not been documented among pastoralists and arable farmers in the Rwenzori region of Western Uganda. The present study investigated the biotic and abiotic indicators for the onset and cessation of rains, 5-day forecasts and seasonal forecasts used by farmers and pastoralists. Forecasts influence farmers' decision-making regarding which crop enterprises to be undertaken in a particular cropping season, especially in areas that experience bimodal rainfall patterns. Crops have varying water requirements, with cereals such as maize requiring a higher number of rain days than do tubers like cassava (Mugalavai et al. 2008). Climate forecasts also influence livestock breeding among pastoralists (Luseno et al. 2003).

The Rwenzori region has bimodal rainfall distribution with short rains (March-May) and long rains (AugustDecember). Farmers tend to plant short-maturing crops like beans in the first season and long-maturing crops like maize in the second season. Five-day forecasts provide information about the length of the dry spells. Long dry spells during the critical growth periods lead to high crop failure (Rao et al. 2011). Changes in onsets and cessations of rains can have negative impacts on crop performance, for example, late onset and early cessation in a particular season could result in high-yield loss for maize (Mugalavai et al. 2008). Farmers prepare their fields in February for the first season and in July for the second season. Harvesting for the first season is in May and June and for the second season is in November and December, depending on the crop maturity period.

In addition to documenting the indicators used in IKF, we examined potential scientific explanations for why the indicators were effective. The study's objective was to assess whether IKF indicators can be incorporated in weather and climate forecasting by policy makers, national meteorology advisories, extension workers, and nongovernmental organizations.

\section{Indigenous knowledge indicators of rain}

Bird phenology has been used to support climate forecasts. Regional bird species used include Abyssinian hornbill (Bucorvus abyssinicus), African pied wagtail (Motacilla aguimp), sparrows, swallows, weaver birds, blue-tailed bee-eater (Merops philippinus), and swifts (Galacgac and Balisacan 2009; Leonard et al. 2013; Ifejika Speranza et al. 2010; Zuma-Netshiukhwi et al. 2013). Bird migration is an important indicator for seasonal forecasts, including the onset and cessation of rains (Zuma-Netshiukhwi et al. 2013). Apart from birds, the seasonal movement of wildlife is another source of early warning information; for instance, a zebra invasion of farmland indicates onset of drought in areas with close proximity of wildlife protected areas in Kenya (Ifejika Speranza et al. 2010). Research has shown that insects used in indigenous forecasts include butterflies, red ants, army worms, dragonflies, termites, and bees (Chang'a et al. 2010; Galacgac and Balisacan 2009; Ifejika Speranza et al. 2010). Literature shows that plants and trees that support climate information include fern-leaf grevillea (Grevillea pteridifolia), baobab tree (Adansonia gregorii), and acacia trees (Acacia sp., Acacia mellifera, Acacia tortilis) (Leonard et al. 2013; Ifejika Speranza et al. 2010). This shows the relevance of biotic factors in IF.

Abiotic indicators include wind, clouds, astrological constellations, and observance of sky, sun, moon, and stars (Gómez-Baggethun et al. 2012; Green et al. 2010; Lefale 2010; Leonard et al. 2013; Mpandeli and Maponya 2013; Roncoli et al. 2002; Ifejika Speranza et al. 2010; Zuma-Netshiukhwi et al. 2013). Farmers also observe the events that happen around orographic features such as mountains. For instance, events such as cloud formation around Mount Kilimanjaro may provide climate information (Ifejika Speranza et al. 2010). Hydrological indicators include observation of seasonal river flow and sea level variation (Kalanda-Joshua et al. 2011; ZumaNetshiukhwi et al. 2013).

Livestock behavior is an important indicator among pastoralists (Ifejika Speranza et al. 2010; ZumaNetshiukhwi et al. 2013). In pastoral communities, observing the intestines of slaughtered cattle is considered a relevant sign for rainfall seasonality (Luseno et al. 2003). The behavior of frogs is keenly observed during the onset of rains (Gyampoh and Asante 2011; Kalanda-Joshua et al. 2011). Research reveals that fish behavior may provide climate information for fishing communities (Leonard et al. 2013). Observance of heat by ordinary farmers without using scientific gadgets has been considered a relevant indicator for early warning systems and rainfall seasonality in rural livelihoods (Nkomwa et al. 2014; Ifejika Speranza et al. 2010; Zuma-Netshiukhwi et al. 2013). This shows that farmers' observations of the environment provide climate information that influences decision-making in rain-fed agriculture.

Nonenvironmentally sensitive indicators include spirituality through rainmakers and traditional diviners (Roncoli et al. 2002; Slegers 2008; Ifejika Speranza et al. 2010). These are mainly from the African traditional religions that involved sacrifices, but the rainfall predictions are not well received by farmers with strong Christian and Islamic religious beliefs (Roncoli et al. 2002; Slegers 2008). 
Beyond Africa, Mongolian pastoralists consult spiritualists in matters related to climate forecasts before their migrations (Marin 2010). These indicators of indigenous forecasts are widely used in Samoa (Lefale 2010), New Zealand (King et al. 2008; Galloway-McLean 2010), Canada (Gearheard et al. 2010), Australia (Green et al. 2010; Galloway-McLean 2010), Spain (Gómez-Baggethun et al. 2012), South Africa (Mpandeli and Maponya 2013), Kenya (Ifejika Speranza et al. 2010), Malawi (KalandaJoshua et al. 2011; Nkomwa et al. 2014), Burkina Faso (Galloway-McLean 2010; Roncoli et al. 2008), Ghana (Gyampoh and Asante 2011), and Botswana (Kolawole et al. 2014). Pastoralists in Western Uganda use IF in adapting to climate change and variability (Nkuba et al. 2019b). Research shows that IF influences arable farmers estimation of onset of rains in Western Uganda (Nkuba et al. 2019a).

Some scholars have reported that indigenous knowledge (IK) forecasts are reliable (Kalanda-Joshua et al. 2011; Lefale 2010; Nkomwa et al. 2014), but others have found them unreliable (Gyampoh and Asante 2011; Roncoli et al. 2002). Reliability of IK forecasts is associated with being site specific, based on local experiences, transmitted in local languages, and easy access and dissemination through farmers' forums as well as farmer-to-farmer extension (Kalanda-Joshua et al. 2011; Lefale 2010; Luseno et al. 2003; Ifejika Speranza et al. 2010). Pastoralists in certain areas seem to have high confidence in the use of IK forecasts in adaptation to droughts in Africa (Luseno et al. 2003; Ifejika Speranza et al. 2010). Climate variability has weakened some of the farmers' trust in IK forecasts, resulting in a search for alternatives (Roncoli et al. 2002). Climate variability is detrimental to the biotic indicators of IK forecasts (Ifejika Speranza et al. 2010).

Plants and trees can be affected by climate change, hence rendering their role as indicators ineffective. Consequently, reliance on nonenvironmental (i.e., abiotic) indicators such as astrological features like stars and the moon has increased (Slegers 2008). Farmers in Peru and Bolivia made rainfall forecasts using stars with a good degree of accuracy (Orlove et al. 2000). IK forecasts are reportedly mostly used by older farmers (above 40 years), with little reference from the younger generation who are even less involved in rural agricultural production where IK is most used (Motsumi et al. 2012; Ifejika Speranza et al. 2010). This situation negatively affects the intergenerational transfer of IK forecasting skills (Ifejika Speranza et al. 2010).

Indicators of IF in Uganda include birds, insects, frogs, wind, clouds, flowering of trees, change in water levels of rivers and lakes, and observance of nighttime temperatures (Nganzi et al. 2015; Okonya and Kroschel 2013;
Orlove et al. 2010). This shows that there is a wide variety of abiotic and biotic environmental indicators for IF, which increase trust, legitimacy, and salience among pastoralists and arable farmers.

\section{Materials and methods}

\section{a. The study area}

The Rwenzori region in Western Uganda where the study was done is characterized by topographic diversity, with mountains and lowlands, wetlands and forests, and agricultural areas. In addition to arable farming, pastoralism thrives in the rangelands as well as game in the wildlife protected areas (WPAs). WPAs include Queen Elisabeth, Kibale, and Mount Rwenzori National Parks and the Tooro-Semiliki Game Reserve (Fig. 1). There are numerous natural and planted forest protected areas (FPAs). The region is also endowed with water bodies such as lakes and rivers, all contributing to rich biodiversity incorporated into local indigenous knowledge systems. The region is found in the Albertine Rift valley, making it prone to earthquakes (Batte et al. 2014).

\section{b. Data collection methods and sample size}

Data were gathered from rural households from August to October 2015. Household surveys were used to gather data in person, using a questionnaire about IKF indicators used in the Rwenzori region, including indicators for onset and cessation rains, 5-day forecasts, and 3-6-month seasonal forecasts. The complete survey is provided in the online supplemental material.

A two-stage stratified approach was used in the sampling of the respondents (Cochran 1963). The firststage units were the agroecological systems (Table 1), and second-stage units were households. The sampling took into consideration pastoralism and arable farming in the selection of the respondents. The 2014 Uganda population census report put the number of households in the area at 102496 households. Raosoft (http:// www.raosoft.com/samplesize.html), a sample size calculator, showed that a statistically acceptable sample size for this population of households at $95 \%$ confidence level and margin of error at $3.5 \%$ was 778 . However, to allow for replacement in the sample of those who might back out of the study, $19 \%$ of the statistically selected sample was included, giving a total study sample of 924. This was also to ensure good size for subsamples (for those who use IF only, and for those who use both SF and IF). After data cleaning, 17 incomplete questionnaires were eliminated from the final analysis. The total sample of the household survey was 907 households. 

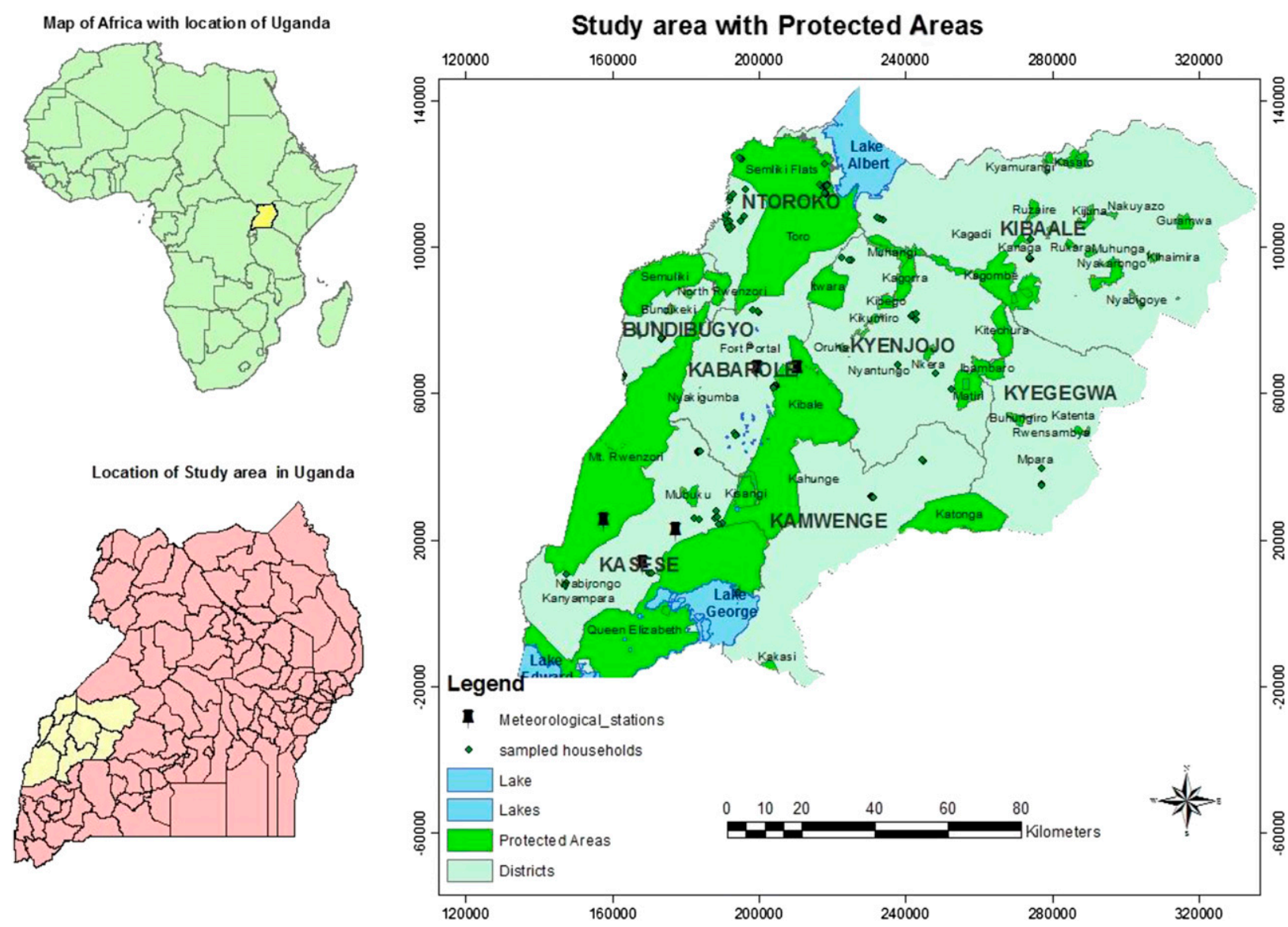

FIG. 1. Location map of the study area.

Focus group discussions (FGDs) were conducted with pastoralists and arable farmers to provide community perceptions on the indigenous forecast indicators. For arable farmers, two separate FGDs were conducted in Kyegegwa District, with the female group comprising 15 women and the male group comprising 16 men. Two other FGDs for arable farmers were conducted in Kabarole District, where the male group comprised 17 men and the female group 15 women. For pastoralists, the FGDs were conducted at Rwebisego village in Ntoroko District. One focus group consisted of 14 women, while the second comprised 18 men. Holding gender-segregated FGDs ensured full participation of the discussants, whereas mixed-gender FGDs would likely have been dominated by the men. Pastoralism is the main livelihood strategy in Ntoroko District, while in the Kyegewa and Kabarole Districts it is arable farming.

Key informant interviews were conducted with scientific experts such as ornithologists, botanists, entomologists, hydrologists, seismologists, and meteorologists to provide expert knowledge on the phenology of the biotic indicators and to explain the observed phenomena behind the abiotic indicators. The experts were from research and academic institutions in Uganda and

TABLE 1. Sample size (source: survey data from 2015).

\begin{tabular}{lccrr}
\hline \hline \multicolumn{1}{c}{ Agroecological zone } & Arable farmers & Pastoralists & Agropastoralists \\
\hline Forested & 122 & 0 & 0 & Total \\
Mountainous & 97 & 0 & 0 & 122 \\
Wetland & 82 & 0 & 0 & 97 \\
Lowland & 197 & 270 & 57 & 82 \\
Mountainous and forested & 82 & 0 & 0 & 524 \\
Total & 580 & 270 & 57 & 907 \\
\hline
\end{tabular}


Botswana. This information was used in the discussion section (section 4) to give explanatory reasons for the behaviors of the indicators. Purposive sampling was employed in selecting the key informants and FDGs.

Data from the household surveys, FGDs, and key informant interviews were analyzed using the Statistical Package of Social Scientists (SPSS) (version 24) statistical software and Nvivo software. The extent of use of the various indicators was obtained from the household survey using frequencies, and thematic analysis was used in investigating the qualitative data from key informants and FGDs.

\section{Results}

The sociodemographic results indicated the following distribution of household respondents according to agroecological zones: $14 \%$ in forested areas, $10 \%$ in mountainous areas, $10 \%$ in wetland, about $9 \%$ in mountainous and forested areas, and $57 \%$ in lowlands. About $64 \%$ were arable farmers, about $30 \%$ were pastoralists, and $6 \%$ were agropastoralists. The majority $(55 \%)$ of the respondents were male. The majority (52\%) of the respondents had attained primary education, while $15 \%$ had an ordinary level education and $29 \%$ had no formal education.

The household surveys showed that there are a wide variety of biotic and abiotic environmental indicators used by farmers and pastoralists in the Rwenzori region. FGDs provided insights into the community perceptions of the indicators. Key informant interviews with various scientists from respective disciplines are shared to elucidate the observations of the farmers and pastoralists in section 4

\section{a. Birds}

The household survey identified 25 species of birds used as indicators. Of these, the white-browed coucal (Centropus uperciliosus) was the most common (Table 2). Many of the species were only mentioned by a few of the respondents. Pastoralists and farmers used different indicator species, and the indicators also varied by location within the region. The FGDs provided additional insight into the use of the indicator species. Key informant interviews suggested potential reasons as to why the indicators work (details in section 4 ). The results indicated that the birds of major importance in providing climate information under indigenous knowledge systems were white-browed coucals, turacos, eagles, swallows, and egrets (Table 2). The participants from both male and female FGDs of pastoralists and arable farmers reported that the white-browed coucal (Centropus supercilious) makes calls before the onset of rains and has been most reliable over the years. The participants from the male and female pastoralist FDGs reported that flocks of eagles were spotted during the onset of rains, while the turacos made calls during the cessation of rains. A participant from the male pastoralist FDG reported the appearance of many doves toward the onset of rains. A key informant reported that birds common at the onset of rains included the white-browed coucal and hornbill, and for cessation it was the Abdim's stork. Some participants of one FDG reported that "when the great blue turraco sounds, then you know there is the sunny period. . there are birds that come to peck fish because the water has already reduced...When the sunny season is coming, there are some birds that come."

\section{b. Plants}

The study showed that the plants most commonly used as indicators were coffee, cocoa and acacia (Table 3 ). The participants from the male FGD of pastoralists reported that bark cloth trees (Ficus natalesis) shade their leaves toward the onset of rains. Participants of the FDG reported that "when the rains are going to start, the flowers of coffee blossom and fall off. . when the rains are on set, the coffee beads will wither but when it wants to rain, the coffee will look nice and show signs of flowering until when the rains will come. It's the same thing for Ficus natalensis. . Then the mangoes. . flowers blossom.'

\section{c. Animal indicators}

The results showed that cattle and frogs play a major role in IKF (Table 4). The participants from both the male and female FGDs of pastoralists reported that cows were playful toward the onset of rains.

The results showed that the behavior of wildlife such as elephants, chimpanzees, crocodiles, and hippopotamuses may be considered to be a relevant indicator of rainfall seasonality. The participants from the male pastoralists' FDG reported that toward the cessation of rains, hippos made loud noises like the roar of a lion in the early morning hours. A key informant reported that wildlife tend to raid crops due to decreased nutritional value of fruits within the protected areas, especially for elephants and chimpanzees.

\section{d. Insect indicators}

Among the insects, red ants (order Hymenoptera; family Formicidae), butterflies (order Lepidoptera), and grasshoppers (order Orthoptera; family Acrididae) were the most important insects in the study area (Table 5). It is worth noting that stomoxys sp. (locally called Kawawa) were an important indicator among the pastoralists. The participants from both male and female FGDs of arable farmers reported that the appearance of red ants, insects 


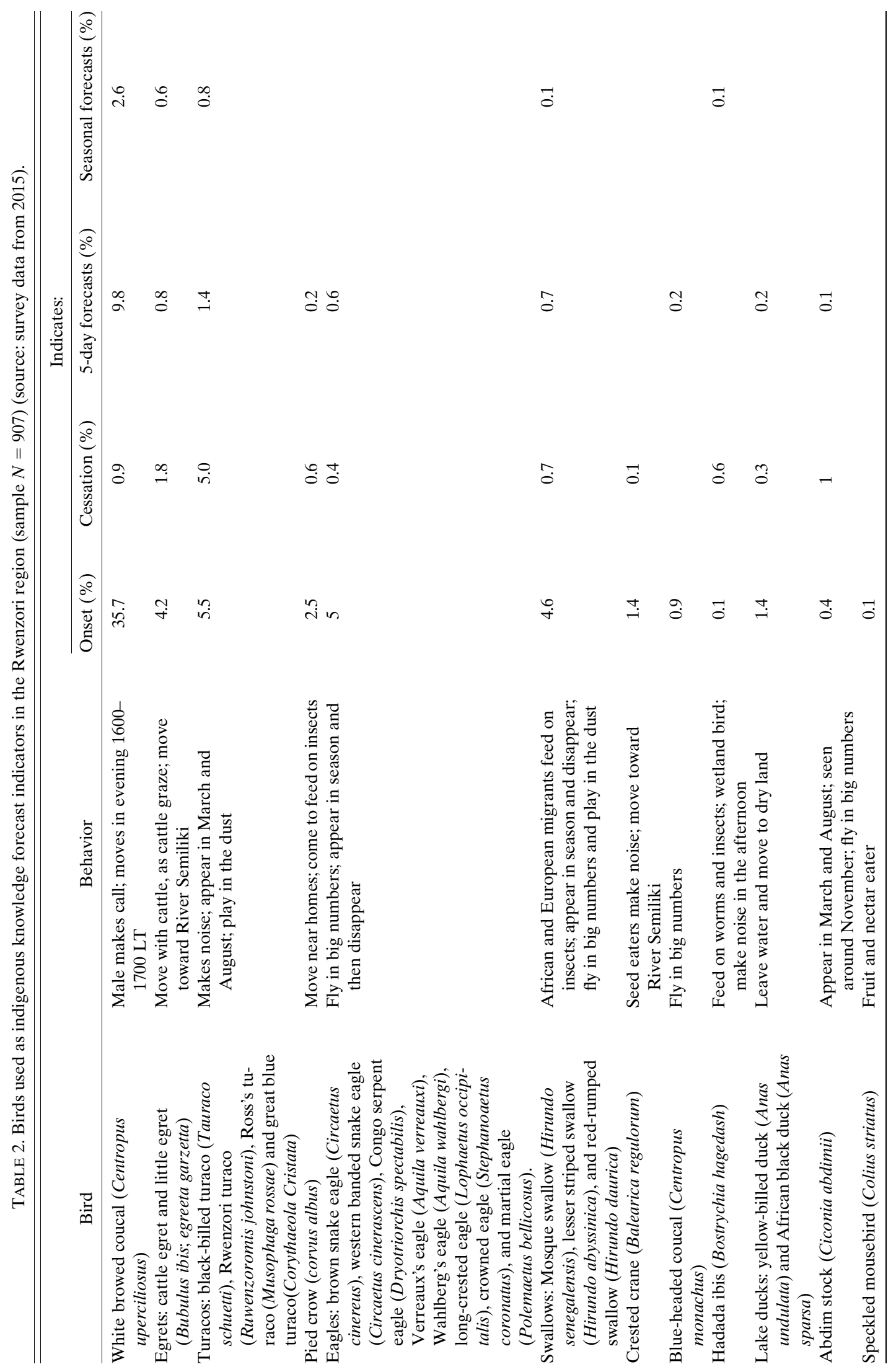




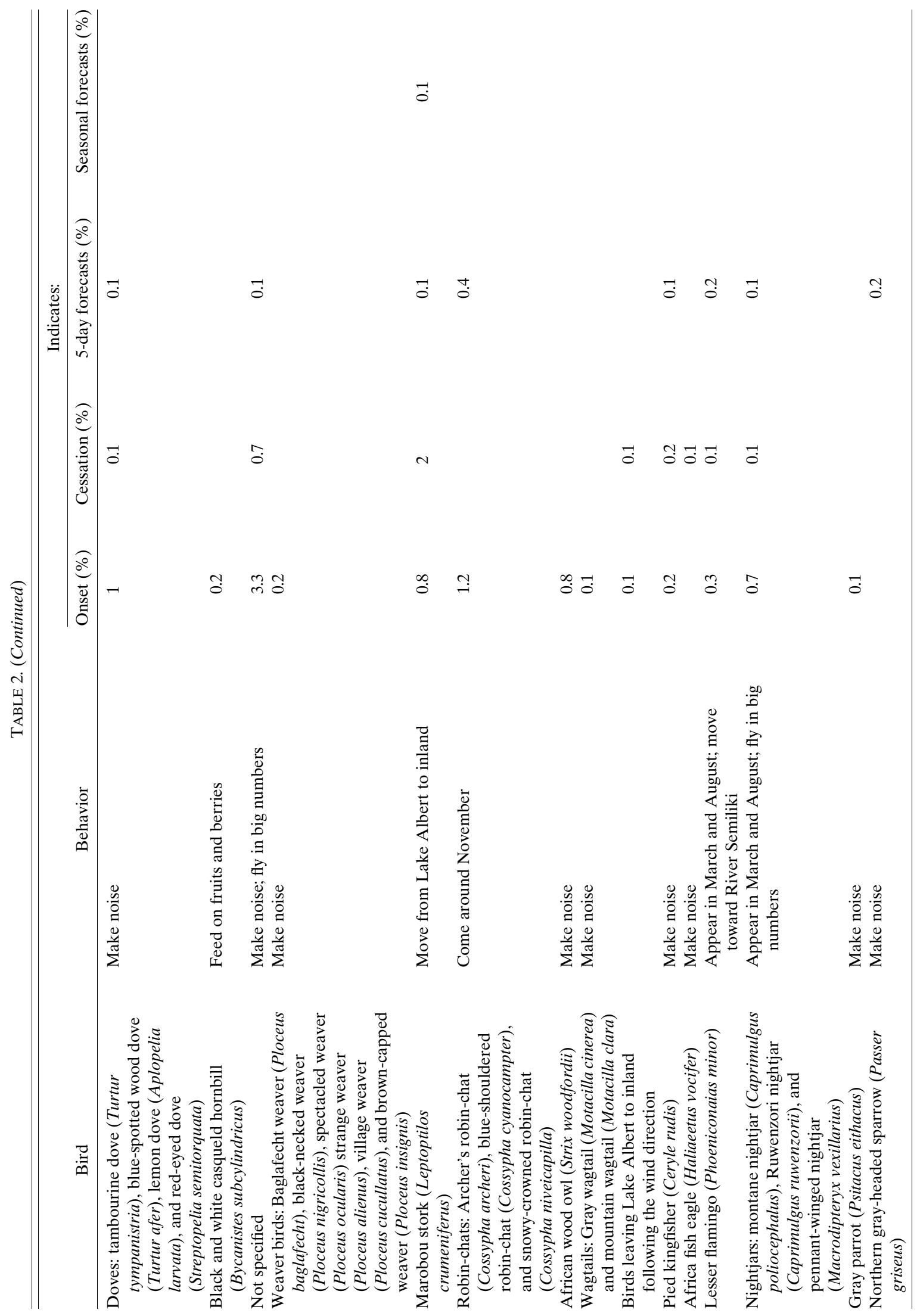


TABLE 3. Plants used as indigenous knowledge forecast indicators in the Rwenzori region $(N=907)$ (source: survey data from 2015).

\begin{tabular}{|c|c|c|c|c|c|}
\hline \multirow[b]{2}{*}{ Plant } & \multirow[b]{2}{*}{ Behavior } & \multicolumn{4}{|c|}{ Indicates: } \\
\hline & & $\begin{array}{l}\text { Onset } \\
(\%)\end{array}$ & $\begin{array}{c}\text { Cessation } \\
(\%)\end{array}$ & $\begin{array}{c}\text { 5-day } \\
\text { forecasts }(\%)\end{array}$ & $\begin{array}{c}\text { Seasonal } \\
\text { forecasts }(\%)\end{array}$ \\
\hline Coffee & Flowering; ripening of berries & 6.9 & 0.9 & 0.8 & 0.6 \\
\hline Cocoa & Flowering & 1.4 & 0.1 & 0.2 & \\
\hline Acacia & Flowering; bring new shoots; shade leaves & 2.0 & 1.8 & 0.3 & \\
\hline Trees & Shade leaves; bring new shoots and leaves & 2.1 & 1.8 & 0.1 & \\
\hline Fruit trees & Flowering & 0.9 & 0.1 & 0.2 & \\
\hline Not specified & Flowering; bring new shoots and leaves & 0.8 & 0.7 & & \\
\hline Tropical coral tree-Erythrina spp & Flowering; shade leaves & 0.9 & 0.8 & 0.1 & \\
\hline Markhamia lutea & Flowering & 0.1 & & 0.1 & \\
\hline Vernonia amygdaiina & Flowering & 0.2 & & 0.1 & \\
\hline Neem & Shade leaves & 0.2 & 0.2 & & \\
\hline Bark cloth tree (Ficus natalensis) & Flowering; shade leaves & 0.7 & 1.7 & 0.1 & \\
\hline Star grass & Withering & 0.1 & & & \\
\hline Banana & Flowering; harvests increase & & 0.1 & & \\
\hline Bambo tree & Flowering & & 0.2 & & \\
\hline Grass & Withering; drying of grass & & 0.4 & & \\
\hline Lantana camara & Withering & & 0.1 & & \\
\hline Pastures & Changes from green to yellowish & & 0.1 & & \\
\hline
\end{tabular}

emerging out of anthills were common indicators toward the onset of rains while butterflies were common toward the cessation of rains. Participants in one FDG reported that "if the red ants in the forest start passing through then you know the rains are almost starting. . .in the bush there are those small ants that are black so if it's going to rain after dry season, you see those insects." During cessation, participants of the FDG reported that "the presence of many butterflies is an indicator of end of the rainy season. During cessation of rains, butterflies come...other insects (apart from butterflies) are many, then they start to disappear...As the end of rain season approaches, all the bees will refuse to leave their hives."

\section{e. Observance of events on Mount Rwenzori}

Observance of the changes in fog and cloud cover on Mount Rwenzori was an important factor in climate forecasts (Table 6). An IK forecaster showed that the events on Mount Rwenzori were important in climate forecasting for the Rwenzori region. It was worth noting that the seasonal calendar of events was important in long-range climate predictions for climate risks such as droughts and floods (Table 6). Observance of seasonal calendar events is important, especially in pastoral communities, because it influences herd mobility and livestock migration.

In watersheds such as the Rwenzori region, the melting of snow on Mount Rwenzori is seen as the increase in river-flow volume in the downstream communities. Farmers in the Karusandara area in Kasese District, which is prone to flooding, said that they keenly observe the changes in cloud cover and snow on
Mount Rwenzori. In extreme cases, downstream communities have experienced flooding. An interview with an IKF forecaster and participants of FGDs stated that farmers in the Rwenzori region were keen to observe the changes on Mount Rwenzori even at distances over $150 \mathrm{~km}$ away. Farmers also noted that the waves on Lake Edward are stronger toward the onset of rains (Table 6).

\section{f. Observance of heat}

The findings show that observance of heat is a significant indicator (Table 6). Participants of one FDG reported that "When you see that there is too much heat while sleeping then you know the rains will start in less than a week. . . and then there is too much heat, the heat of rains is not the same as that of the sun. You find that even the people's bodies attract that heat... a lot of heat/high temperatures at night like for example if every day you cover yourself with a blanket but then now you feel so hot and you place away the blanket, there you know it will rain." This suggests that farmers can monitor the heat without using scientific tools like thermometers.

\section{g. Hydrological indicators}

Hydrological factors such as observing the river flows and an abundance of fish in lakes and rivers in the study area were used in the climate forecasts (Table 6). The participants from both male and female FGDs of pastoralists and arable farmers reported that water levels of the rivers increased toward onset of rains. One participant reported that "during onset of the rains...the rivers water levels become higher, there you know the rains 


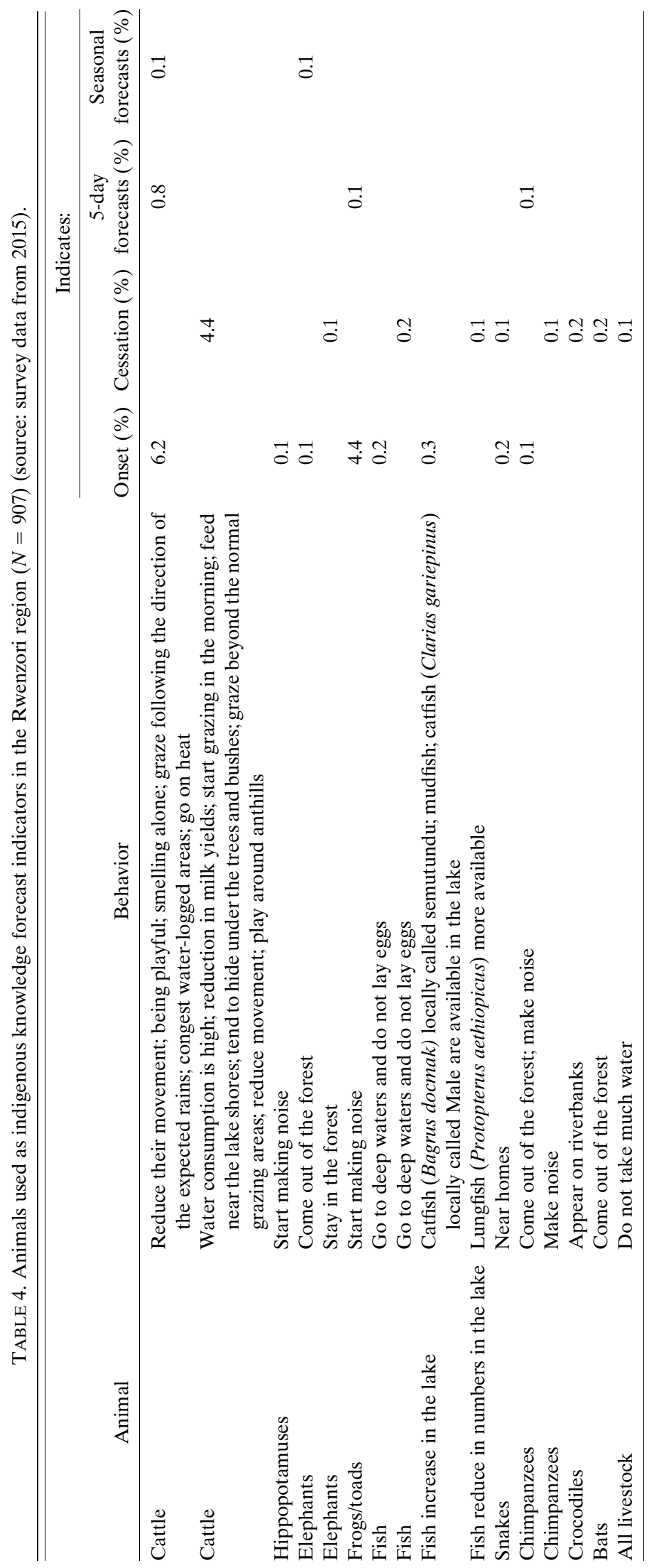




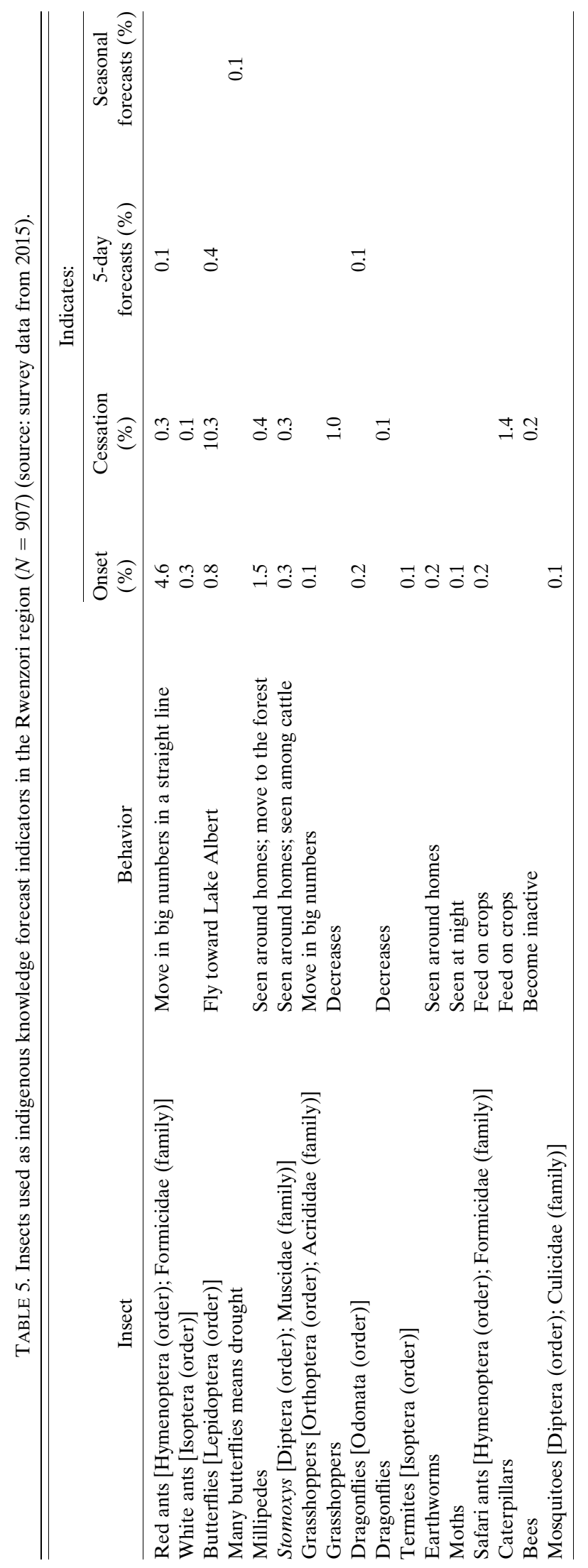




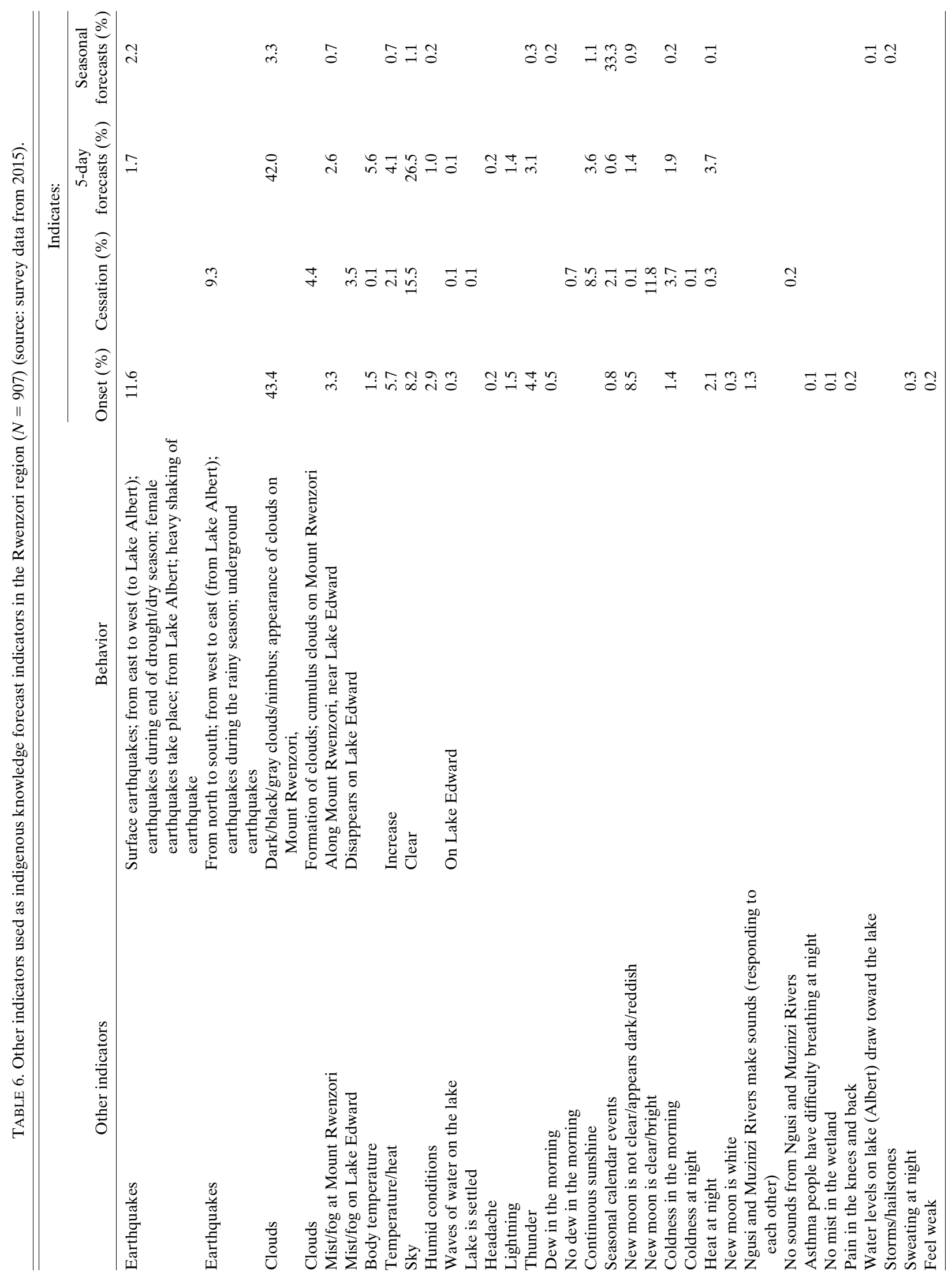


TABLE 7. Winds used as indigenous knowledge forecast indicators in the Rwenzori region $(N=907)$ (source: survey data from 2015).

\begin{tabular}{|c|c|c|c|c|c|}
\hline \multirow[b]{2}{*}{ Wind } & \multirow[b]{2}{*}{ Direction } & \multicolumn{4}{|c|}{ Indicates: } \\
\hline & & Onset (\%) & Cessation (\%) & $\begin{array}{c}5 \text {-day } \\
\text { forecasts }(\%)\end{array}$ & $\begin{array}{c}\text { Seasonal } \\
\text { forecasts }(\%)\end{array}$ \\
\hline Congo winds & Blows from west to east & 2.8 & 1.2 & 1.7 & 0.1 \\
\hline Musasi & Blows from west to east & 9.7 & 3.0 & 2.9 & 1.3 \\
\hline Ndowa & Blows from east to west & 4.1 & 11.4 & 3.2 & 0.8 \\
\hline Wabubu & Blows from west to east & 0.7 & 0.3 & 0.1 & 0.1 \\
\hline Muzizi River & Blows from west to east & 1.5 & 0.4 & 0.8 & 0.1 \\
\hline Kinjura & Blows from north to south & 0.2 & 0.4 & 0.2 & 0.3 \\
\hline Kitagweda & Blows from east to west & 0.2 & 0.2 & 0.1 & \\
\hline Wabuho & Blows from west to east & 0.4 & & & \\
\hline Lake Albert wind & Blows from west to east & 0.8 & 0.4 & 0.3 & \\
\hline Rwenzori wind & From the mountains & 0.3 & & 0.3 & \\
\hline Whirl winds & & 1.2 & 1.1 & 0.2 & 0.1 \\
\hline Cold winds & & 2.0 & 2.0 & 2.6 & 0.4 \\
\hline Lake George winds & From Lake George to inland & 0.1 & 0.2 & 0.2 & \\
\hline Hot winds & & 1.5 & 0.4 & 2.0 & 0.1 \\
\hline Not specified & $\begin{array}{l}\text { Blows from west to east; blows from east } \\
\text { to west }\end{array}$ & 17.3 & 10.4 & 4.7 & 1.7 \\
\hline Ihunga & & 0.3 & & & \\
\hline Kasambura winds & From south to north & 0.3 & 1.4 & & \\
\hline Ituri winds & Blows from west to east & 0.1 & & & \\
\hline Butuku winds & & 0.2 & 0.1 & & \\
\hline Tooro winds & Blows from east to west & 0.2 & 0.4 & & \\
\hline Bundibugyo winds & & 0.1 & 0.1 & 0.1 & \\
\hline Bunyoro winds & Blows from west to east & 0.1 & & & \\
\hline
\end{tabular}

are on setting." Another reported that "When the sunny period is on setting, we see from the water or the lakes, its color changes from the color it had to a brownish color."

\section{h. Meteorological indicators}

Meteorological factors such as wind and clouds were essential climate predictors (Tables 6 and 7). The participants from both male and female FGDs of pastoralists and arable farmers reported that the wind blew from the west to the east toward the onset of rains. The participants from the male pastoralists' FDG reported that hot winds blow toward the onset of rains. The participants from both male and female FGDs of pastoralists and arable farmers reported the appearance of dark black clouds called nimbus clouds toward the onset of rains, an observation echoed by the household survey (Table 6). One participant of an FGD reported that "Most of the times when the rains want to come, you find the cloud of nimbus in the sky, then the rains will start. That is how I know that now the rains are going to start. . Too much wind takes away the rain."

Local winds with direction of flow (mostly westerlies and easterlies) are important indicators (Table 7). A meteorologist reported that the Rwenzori region's rainfall seasonality is greatly influenced by Congo basin winds, namely, Congo winds and Ituri winds, as they are locally called by the farmers. A participant of the FDG reported that "Sometimes when it wants to rain you see strong winds that shows that the rains are coming." A key informant reported that the Congo forest and Mount Rwenzori had a strong influence on the rainfall seasonality in the Rwenzori region.

\section{i. Earthquakes}

The Rwenzori region being located in the Rift valley, earthquakes were used as IF indicators (Table 6). The FGD participants from female arable farmers in Kyenjojo reported that they experienced earthquakes moving from west to east during the onset of rains. One participant reported that "for the sunny period, there will be earthquake. That's what I know before the sun begins...there is an earthquake at the beginning of the sunny season and also beginning of the rain season."

\section{j. Astronomical indicators}

Astronomical indicators such as stars, sun, and moon were used in predicting rainfall seasonality (Tables 6 and 8). Participants of one FDG reported that "Even the moon starts to be reddish, it's also an indicator that it's going to be sunny... When the sunny season is going to come, you find where the sun emerges from, it's red and with no clouds so you know that this sun has shown that there will be sunshine." A key informant reported that 
TABLE 8. Stars used as indigenous knowledge forecast indicators in the Rwenzori region $(N=907)$ (source: survey data from 2015).

\begin{tabular}{lcccc}
\hline \hline & \multicolumn{4}{c}{ Indicates: } \\
\cline { 2 - 5 } \multicolumn{1}{c}{ Stars } & $\begin{array}{c}\text { Onset } \\
(\%)\end{array}$ & $\begin{array}{c}\text { Cessation } \\
(\%)\end{array}$ & $\begin{array}{c}\text { 5-day } \\
\text { forecasts }(\%)\end{array}$ & $\begin{array}{c}\text { Seasonal } \\
\text { forecasts }(\%)\end{array}$ \\
\hline Black stars & 0.1 & & & 0.1 \\
Not specified & 3.6 & 2.9 & 0.7 & 0.7 \\
\hline
\end{tabular}

some pastoralist elders observe stars for drought early in the morning, between 0400 and 0600 local time (LT).

\section{k. Rainmakers}

During the study, FDGs were held with rainmakers. A key informant reported that "people come and consulted me before having social functions such as weddings about the possibility of rainfall on the planned day.... inherited the powers of rain making from my father." Rainmakers (commonly called spiritualists) were consulted in some cases about climate predictions in the Rwenzori region. Rainmaking is an inherited practice that started during the period when the Chwezi kingdom reigned in this region. A participant of a female FDG reported that the preeminence of Christianity has diminished the influence of rainmakers in the study area.

\section{Discussion}

This study has documented the use of biotic and abiotic indicators of precipitation patterns by farmers and pastoralists in livelihood decision-making and also has identified distinctive subcategories of indicators under each of the four broad categories. The discussion below isolates these subcategories systematically.

\section{a. Biotic indicators}

\section{1) BIRDS}

The study findings show that the white-browed coucal (Centropus uperciliosus) and African and European migrants like swallows are considered a significant indicator of rainfall seasonality (Table 2). Literature shows that birds are widely used as IKF indicators in countries such as Australia (Green et al. 2010; Leonard et al. 2013), Tanzania (Chang'a et al. 2010; Chengula and Nyambo 2016), Kenya (Luseno et al. 2003; Ifejika Speranza et al. 2010), Botswana (Kolawole et al. 2014), Burkina Faso (Roncoli et al. 2002), and Malawi (Kalanda-Joshua et al. 2011). There are no obvious contradictions between what we would expect from scientific forecasts and bird phenology as indicators of the onset and cessation of rains. Ornithologists stated the following:
Some migrants come around the equator during the onset of rains and depart during cessation. Other migrant birds are around the equator during cessation and depart during onset of rains. European migrants come to Africa at onset of winter period in their habitants and go back at onset of summer. African migrants from southern Africa fly to equator at onset of winter in southern Africa and fly back at onset of the summer period...Birds activities such as breeding increases with resource availability such as insects, fruits, seeds which are synchronized with rainfall seasonality. The movement of migrants provides seasonal climate information...Birds are active during the feed of the young. . .if weather changes the birds miss the food and this alters their migration patterns.

An ornithologist said that migrations of birds (migrants and resident birds) is an important indicator of seasonal forecasts as well as the onset and cessation of rains in the farming community.

Research supports the observations of the ornithologists, which show that bird phenology follows the pattern of the onset and cessation of rains in a given ecosystem. Bird phenological studies have shown that birds are most active in farming communities during their breeding seasons when there is abundance of food for themselves and their young ones, and this makes them a potential important indicator for the onset and cessation of rains (Brown et al. 1982; Fry et al. 1992a, 2000, 2004; Hulme et al. 2013; Pearce-Higgins et al. 2014). Hence this high feeding activity together with noise from the nestlings and movement of the adults to and from the nests bringing food provides climate information to farmers. Furthermore, the seed eaters such as weavers are active during the cessation of rains, especially during the harvest period. Similarly, fruit eaters such as wagtails, doves, and insectivores such as nightjars breed toward the cessation of rains in sequence with the birth of young (Hulme et al. 2013). Birds make calls that are interpreted by farmers as information about rainfall seasonality; for example, the male white-browed coucal (Centropus superciliosus) makes calls to females during breeding, and the yellow-billed duck (Anas undulata) makes calls during incubation, but these calls provide information about the onset of rains in arable farming communities (Irwin 1986; Newman 1982). Seedeaters such as the lesser striped swallow (Hirundo abyssinica) and tambourine dove (Turtur tympanistria) make calls to their young when feeding them, and the calls provide information to the farmers about end of the rainy season (Fry et al. 1992b; Morel et al. 1986).

Male birds make calls to the females, and the calls are interpreted as IKF indicators. For example, the male white-browed coucal makes calls to the females during the onset of rains. This bird is so popular in the farming 
communities for its call that some farmers find it useful and it is called the rain bird in the Rwenzori region. During the FGDs, participants noted that when the white-browed coucal makes its call, then onset of rain could be expected in the next two to three days. This indicator was reported as the most reliable onset indicator in the Rwenzori region (Table 2).

The review of literature indicates that change in the onset and cessation of rains alters the availability of food, which affects the survival of young. Birds avoid breeding during seasons of resource scarcity. On one hand, this makes birds an unreliable indicator of rainfall seasonality. Change in rainfall seasonality alters bird migrations and breeding, which are important IF indicators. On the other hand, birds are good indicators of climate change. Climate change contributes to the mismatch between resource availability and breeding of birds (Pearce-Higgins et al. 2014; Visser et al. 2012).

The spatiotemporal availability of food also influences the birds' migration and the activity of resident birds. Other factors that influence birds' migration are the changes in temperature and photo period in their breeding areas. Migratory birds tend to arrive at the onset of rains and depart at the cessation of rains around the equator and vice versa, depending on whether they are African migrants or European migrants such as the lesser striped swallow (Hirundo abyssinica), Abdim's stork (Ciconia abdimii), Wahlberg's eagle (Aquila wahlbergi), black kite (Milvus mugrans), or village weaver (Ploceus cucullatus) (Brown et al. 1982; Fry et al. 1992b; Urban 1982). This observance provides information about the onset and cessation of rains to the farming community since the birds practice the seasonal migration patterns. The arrival and departure of migratory birds provide long-range climate information of three to six months to farmers. Nevertheless, the migration has been affected by climate change. Literature has shown that the first arrival date of migrating birds has changed over time (PearceHiggins et al. 2014). This is consistent with farmers' observations in the change of the onset and cessation of rains. The migration of birds in the tropics (both palaearctic and African migrants) is more influenced by rainfall seasonality than temperature, and this is an indirect driver of resource availability (Grant et al. 2000; Pearce-Higgins et al. 2014).

\section{2) PLANTS}

Tree phenology is influenced by climate seasonality. Some trees flower during the cessation while others flower during the onset of rains. Tree phenology may provide climate information for rain-fed agriculture for decisionmaking and farm planning in relation to the varying cropwater requirements. Annual crop production is sensitive to the status of soil-water availability during the productive and reproductive stages, which is influenced by the onset and cessation of rains. The poor local specificity of scientific climate forecasts makes farmers use biotic environmental indicators such as trees, insects, and birds in their localities to provide climate information.

The findings show that Markhamia lutea, Acacia spp., Ficus natelensis, and Erythrina sp. are essential indicators of the onset of rains (Table 3). There is some consistency between what we would expect from scientific forecasts and farmers' use of plant phenology as indicators of the onset and cessation of rains. A botanist stated that

during onset of rains, plants start budding. After budding, flowering takes place and for some plants this may be 3 weeks after onset of rains. During water stress conditions, plants reduce the vegetative production and flowers produce seeds as survival mechanism. . . onset of rains triggers cell division which influences flowering of plants. The apical bud produces a hormone florgen that triggers flower formation. Buds are dormant during cessation of rains.

This implies that there is a time lag between the onset of rains and when the plants respond to a change in water availability. This shows that plant indicators may not be accurate signs for the onset and cessation of rains. Literature shows that plants are widely used as IF indicators in the following countries: Australia (Green et al. 2010), New Zealand (King et al. 2008), Tanzania (Chengula and Nyambo 2016), Botswana (Kolawole et al. 2014), Kenya (Ifejika Speranza et al. 2010), and Malawi (Kalanda-Joshua et al. 2011).

Trees such as Markhamia lutea, Acacia spp., and Erythrina sp. flower during the onset of rains, and Ficus natelensis shade their leaves during cessation as a response to availability of water in their root zones (Kushwaha et al. 2011; Sekhwela and Yates 2007). Plant phenological studies have shown that some trees flower during the onset of rains because of low stem-water status while some flower during the cessation of rains because of the high stem-water status (Broadhead et al. 2003; Singh and Kushwaha 2005). Availability of water in the root zone is a key factor to tree phenology due to rainfall seasonality (Kushwaha et al. 2011). Apart from root zone water availability and stem-water status, the presence of pollen agents such as insects, birds, and wind (depending on the onset and cessation of rains) play a major role in the flowering of trees (Bendix et al. 2006; Cortés-Flores et al. 2015; Singh and Kushwaha 2006).

\section{3) ANimal IndiCATORS}

\section{(i) Wildlife}

The study shows that the behavior of wildlife such as chimpanzees and elephants may be an indicator of the 
onset and cessation of rain (Table 4). Literature shows that wildlife behaviors are widely used as IKF indicators in Kenya (Ifejika Speranza et al. 2010) and Australia (Green et al. 2010). There appears to be some consistency between what we would expect from scientific forecasts and farmers' use of wildlife phenology as indicators of the onset and cessation of rains. Research shows wildlife phenology follows the pattern of onset and cessation of rains in a given ecosystem. Literature has shown that crop raiding by chimpanzees occurs during the months of forest fruit scarcity and cultivated fruit availability (Hockings et al. 2009; Moscovice et al. 2007; Tweheyo et al. 2005; Yamakoshi 1998). Chimps have high preference for fruits with high sugar content such as bananas, papaws, and mangoes, but other crops like maize, rice, and cassava are also consumed during the crop raids (Hockings et al. 2009; Naughton-Treves 1998; Tweheyo et al. 2005). Animal phenological studies have shown that crop raiding by elephants is due to insufficient availability of essential nutrients such as sodium in their forage (Hold $\varnothing$ et al. 2002; Rode et al. 2006), which is readily available in bananas and sweet potatoes during harvest periods (Naughton-Treves 1998; Rode et al. 2006). Studies done in Kibale National Park showed that climate change was reducing the nutrient content of forest fruits, which could result in increasing crop raids by wildlife (Chapman et al. 2005; Rothman et al. 2015). The literature indicates that wildlife raids follow the rainfall seasonality pattern.

\section{(ii) Livestock}

The results show that livestock behavior may be an important indicator of the onset of rains (Table 4). Literature shows that livestock behaviors are widely used as IKF indicators in Kenya (Luseno et al. 2003; Ifejika Speranza et al. 2010) and Tanzania (Chengula and Nyambo 2016). There are no evident ambiguities between what we would expect from scientific forecasts and farmers' use of livestock behaviors as indicators of the onset and cessation of rains. A livestock scientist reported the following:

After onset of rains, some animals go on heat and tend to be playful. This is because of availability of pastures that provides enough nutrients including energy for both maintenance and production. Production includes pregnancy, producing milk and production of semen. Being playful is part of the mating activities. Female cows may be observed attempting to jump on other females. Breeding at onset of rains attempts to synchronize availability of pastures with requirements of feed at calving time...Sniffing the behind of females by male animals is related to mating and is triggered by production of hormones that can trigger ovulation in females...reduction in movement is because pastures are more readily available. Grazing in the direction on the rains is due to livestock smelling water up to distance of $3 \mathrm{~km}$ from where it rained earlier. . After onset of rains, there is availability of pastures and water resulting into improvement of the body condition leading to change in the appearance of body hair of livestock. The changes may have time lag of up to 3 weeks. At cessation of rains, cattle graze selectively on tender grass resulting into grazing beyond the normal grazing areas. . .Reduction in movement is because pastures and water are readily available. In case the water is further away from the homestead, then they graze near the water source such as river, lake or stream...Feeding on anthills is for provision of mineral such as iron that may be deficient for the physiological needs such as pregnancy. Termites bring fresh soil from underground that is rich in minerals that are essential for livestock needs.

This suggests that there is a time lag between the actual occurrence of the onset of rains and the observance of livestock behaviors.

\section{(iii) Frogs}

The results indicate frog calls as a significant indicator for the onset of rains (Table 4). Literature shows that frogs are widely used as IKF indicators in Tanzania (Chang'a et al. 2010; Chengula and Nyambo 2016), Kenya (Luseno et al. 2003; Ifejika Speranza et al. 2010), and Malawi (Kalanda-Joshua et al. 2011). There appears to be some consistency between what we would expect from scientific forecasts and farmers' use of frog phenology as indicators onset and cessation of rains. Research shows that frog phenology follows a pattern of the onset and cessation of rains in a given habitant. Animal phenological studies have shown that explosive breeding frog species calling was triggered by the onset of rains (Saenz et al. 2006; Schulte and Lötters 2013). The calls by males are made during the frogs' breeding season, which is associated with avoidance of predators during the dry season and desiccation that decreases the survival of toads, especially in places that do not have permanent water flow (Saenz et al. 2006; Schulte and Lötters 2013).

\section{(iv) Fish}

The study findings reveal that fish are a noteworthy indicator of rainfall seasonality (Table 4). Literature shows that fish behaviors are widely used as IKF indicators in Australia (Green et al. 2010; Leonard et al. 2013), Tanzania (Chengula and Nyambo 2016), and Kenya (Ifejika Speranza et al. 2010). There appears, here, to be some consistency between what we would expect from scientific forecasts and farmers' use of fish behaviors as indicators of the onset and cessation of 
rains. The onset of rains triggers the resource availability for fish resulting in spawning. Research shows that fish behavior in the tropics follows the pattern of the onset and cessation of rains in a given catchment. Fish ecology studies have shown that fish food such as aquatic insect larvae for Diptera such as mosquitoes, Odonata such as dragonflies, and Coleoptera increase in abundance during the onset of rains (Dadebo et al. 2014; MwebazaNdawula, 1984; Yatuha et al. 2013) and become important resources for juvenile fish such as Claris spp. and Bagrus docmak (Aruho et al. 2013; Dadebo et al. 2014). Claris spp. and Bagrus docmak breeding is mostly at the onset of rains when resources are readily available (Ochumba and Ala 1992). Inland lake fish are associated with upstream migration during the onset of rains and downstream migration during the cessation of rains (Ochumba and Ala 1992).This suggests that availability of fish during the rainy season may provide climate information for farmers. Dragonflies are common in wetland areas because the adult flies feed on aquatic food (Elzinga 1987).

\section{4) INSECTS}

The study shows red ants as relevant indicators for the onset of rains, and butterflies and grasshoppers as significant indicators for the cessation of rains (Table 5). Literature shows that insects are widely used as IKF indicators in Australia (Leonard et al. 2013), Tanzania (Chang'a et al. 2010; Chengula and Nyambo 2016), Kenya (Luseno et al. 2003; Ifejika Speranza et al. 2010), Burkina Faso (Roncoli et al. 2002), and Malawi (Kalanda-Joshua et al. 2011). There are no noticeable inconsistencies between what we would expect from scientific forecasts and farmers' use of insect phenology as indicators of the onset and cessation of rains. An entomologist said the following:

Red ant movement increases during onset of rains because there is plenty of food. . .Migration of butterflies usually at onset of rains or toward end of dry season to lay eggs. During rainy season, there are many caterpillars. At onset of rains the eggs turn into caterpillars when there is plenty of food. Birds feed on butterflies especially larval stage in form of caterpillars...The short horned grasshoppers are foliage eaters. They are more seen at onset of rains as part of their hatching behavior. They lay eggs in the soil when they anticipate food. Eggs hatch at the set of rains. The heat in dry period incubates the eggs toward the end of dry period. . Safari ants are predators to earthworms, white ants, termites. During the dry period, they are underground. Only appear in moist soils during onset of rains. . . Millipedes are mostly seen in rain season because they feed on organic matters under moist conditions.

This suggests that rainfall seasonality influences insect behavior. The changes in insect behaviors are observed by the farmers as they implement the various crop management practices. Research supports the observations of the entomologist, which show that insect phenology is in sequence with the onset and cessation of rains in a given habitant. Research has shown that the seasonality of insect activity is influenced by adequate availability of food; adequate environmental conditions such as moisture, humidity, and temperature; phenology of the host plants; and the presence of predators, parasites, and pathogens, which happen at onset or cessation depending on the insect (Novotny and Basset 1998). Wind plays an important role in the migrations of insects, especially so for airborne insects during the onset and cessation of rains, adverse conditions such as droughts and scarcity of food (Bale and Hayward 2010). Literature shows that the onset of rains is one of the triggers for tropical insect activity such as beetles (Wolda 1978). The onset of rains triggers the production of young leaves, which are the main resource base for Hymenoptera and Hemipteran (Novotny and Basset 1998; Wolda 1978). Ficus tree young leaves are a high quality resource base for Hemipterans (Novotny and Basset 1998), which are food for birds such as the pennant-winged nightjar (Macrodipteryx vexillarius) (Fry and Harwin 1988). Red ants (order Hymenoptera, family Formicidae) are commonly seen at the onset of rains because they are adapted to high rainfall distribution in rain forest ecosystems (Beugnon and Déjean 1992). Insects have adaptive properties that make them survive adverse conditions through diapause (Bale and Hayward 2010; Fand et al. 2012); for example, grasshopper (order Orthoptera) eggs are in a state of quiescence during the dry seasons and droughts and only hatch when soil moisture is adequate at the onset of rains (Maiga et al. 2010). Grasshopper diapause can last up to eight months (Maiga et al. 2010), making some insects well adapted to climate change (Bale and Hayward 2010). Interestingly, the flying insects such as dragonflies are a good resource base for migrant birds (Brown et al. 1982; Fry et al. 2000, 2004), hence the link between birds and insects as indicators of rainfall seasonality. Entomological studies done in the Rwenzori region in Western Uganda showed that Stomoxys calcitrans breed during the onset of rains but are adversely affected by the dry season (Kangwagye 1974; Parr 1959). The onset of rains provides good conditions in open grazing areas with moist rotted dung that enables eggs to hatch and the pupae to emerge into adult flies (Parr 1959). In the dry seasons, cattle kraals moist with rotted cow dung and urine provide good conditions for breeding (Parr 1959). These insects are eaten by cattle egrets among grazing cattle and buffaloes (Urban 1982). 


\section{b. Observance of events on Mount Rwenzori and heat}

\section{1) Observance of eVents on Mount RWENZORI}

The results showed that observance of events on Mount Rwenzori is an important IKF indicator. Research has shown that observance of events on Mount Kilimanjaro is an IKF indicator for farmers in Kenya and Tanzania (Chengula and Nyambo 2016; Ifejika Speranza et al. 2010). This suggests that events on topographical features like mountains provide predictions of rainfall in their locality.

\section{2) OBSERVANCE OF HEAT}

The results showed that observance of heat is an important IKF indicator. A meteorologist revealed that warm winds are an important predictor of rainfall. Research shows that observance of heat is used as an IKF indicator in Kenya and Tanzania (Chengula and Nyambo 2016; Ifejika Speranza et al. 2010).

\section{c. Abiotic indicators}

\section{1) HydrologicAL}

The results show that river flow is an important indicator of the onset of rains (Table 6). Literature shows that hydrological indicators are widely used as IKF indicators in Kenya (Ifejika Speranza et al. 2010), Tanzania (Chengula and Nyambo 2016), and New Zealand (King et al. 2008). This indicator is valid in providing rainfall predictions because river flow patterns are in sequence with the onset and cessation of rains. A hydrologist reported the following:

Following the onset of rains, river flow upstream increases especially in highlands and mountainous areas. River flow increases in velocity as it flows through narrow gorges in the mountainous areas. High meandering of a river, results into increased velocity. As the turbulent water increases downstream, it hits river banks with high speed making a lot of noise. The river volume is much lower upstream but increases as more streams flow into the river downstream. Following cessation of rains, river flow decreases upstream and consequently the velocity reduces as the flow goes downstream.

This suggests that the hydrological indicator has a time lag between the onset and cessation of rains happens and when it is observed. In the case of the Rwenzori region, streams start in mountains. The river flow increases as more streams join the river and, being a mountainous area, there is a significant of meandering of the river through valleys. Research supports the observations of the hydrologist, showing that river flow patterns are in sequence with the onset and cessation of rains. Literature shows that river flow volume increases during the onset of rains as the stream passes through the riverine gorges especially for riverbeds that have clayey or rocky soils with low infiltration (Bobba et al. 1995; Davie 2008). The velocity of the river increases with change in altitude of terrain, and meandering river channels become a turbulent flow that leads to loud noises in the river gorges as the streamflow hits the riverbanks at high velocities (Shaw et al. 2010). It is common for communities downstream of the river gorge or flood plain to observe increased water levels while upstream communities are experiencing the onset of rains; the river flow volume and speed decrease during the cessation of rains (Shaw et al. 2010). This is a plausible explanation for the observation of farmers that the onset of rains in the mountain ranges of Rwenzori results in increased volume of rivers downstream due to the rain shadow effect (Davie 2008).

\section{2) Meteorological}

Environmental abiotic indicators play an important role in IF. The findings show that wind is a significant indicator of the onset and cessation of rains (Table 7). Literature shows that wind movement is widely used as an IKF indicator in countries such as Canada (Gearheard et al. 2010; Weatherhead et al. 2010), Australia (Green et al. 2010), New Zealand (King et al. 2008), Samoa Islands (Lefale 2010), Tanzania (Chang'a et al. 2010; Chengula and Nyambo 2016), Kenya (Luseno et al. 2003; Ifejika Speranza et al. 2010), and Malawi (KalandaJoshua et al. 2011). This indicator is valid in providing rainfall predictions because wind movement follows a sequence with the onset and cessation of rains. Research shows that wind movement is in sequence with the onset and cessation of rains. Literature has shown that local winds greatly influence the rainfall seasonality of a locality (Aguado and Burt 2010; Ahrens 2012; Lutgens et al. 2001).

Local winds are due to a pressure difference that emanates from unequal Earth-surface heating (Lutgens et al. 2001). One of the main predictors of the climatology of the Rwenzori region, which lies at the equator, is the intertropical convergence zone (ITCZ), which is a zone of low pressure where winds converge (Basalirwa 1995; Ogallo 1989; Ogallo et al. 1988). As local winds cross over lakes such as Lakes George, Albert, Edward, and Victoria, the change in speed inhibits or enhances cloud formation leading to rainfall (Ahrens 2012). The Rwenzori region experiences winds that are called by different names locally depending on what farmers perceive to be the locality of origin. Large terrestrial barriers such as Mount Rwenzori influence rainfall 
seasonality in the region due to the foehn effect on the windward and leeward sides (Aguado and Burt 2010; Ahrens 2012; Barry and Chorley 2009). Wind is used both in IK systems and meteorological sciences in climate forecasting, providing reliable climate information in farming communities (Nganzi et al. 2015). This suggests that IKF is consistent with scientific forecasts. Literature shows that winds from the Congo basin forest are among the rainfall predictors for Western Uganda (Leroux 2001). Equatorial westerlies are warm air masses that are associated with the onset of rains, and easterlies are cold air masses that are associated with the cessation of rains (Barry and Chorley 2009). Whirlwinds are due to wind movement causing rotation of rising air from the hot Earth surface. This phenomenon can happen any time and is not due to rainfall seasonality.

The findings show that clouds are significant indicators of the onset and cessation of rains (Table 6). Literature shows that clouds are widely used as IF indicators in Canada (Gearheard et al. 2010; Weatherhead et al. 2010), Australia (Green et al. 2010), New Zealand (King et al. 2008), Samoa (Lefale 2010), and Kenya (Luseno et al. 2003; Ifejika Speranza et al. 2010). Research shows changes in cloud cover are in pattern with the onset and cessation of rains. Literature shows that the formation of nimbus clouds on mountainous or flat terrain is associated with the onset of rains, while cumulus clouds are associated with the cessation of rains (Aguado and Burt 2010; Ahrens 2012; Barry and Chorley 2009; Lutgens et al. 2001). Clouds are used by both IK systems and scientific forecasting, providing reliable climate predictions (Nganzi et al. 2015). This suggests that IF is in agreement with scientific forecasts.

\section{3) Geological}

The findings show earthquakes may, in certain areas, be used as an indicator of the onset and cessation of rains (Table 6). A seismologist stated that the "Albertine region is highly prone to earthquakes because of its location along the rift valley. Rainfall can induce earthquakes but earthquakes cannot predict rainfall." This indicates that the expert disagrees with farmers that earthquakes can predict rainfall seasonality. However, it suggests that there is a time lag between the onset of rains and the occurrence of earthquakes. This calls for further research. Seismic studies have shown that the Albertine Rift experiences earthquakes (Batte et al. 2014; Lindenfeld and Rümpker 2011; Lindenfeld et al. 2012). Seismic studies done in Germany, Switzerland and the Canary Islands have shown that there are raintriggered earthquakes (Husen et al. 2007; Jiménez and García-Fernández 2000; Kraft et al. 2006). Albertine seismic studies have shown that about 800 earthquakes of varying seismic strengths take place per month, with some being too weak to be felt by local populations (Batte et al. 2014; Lindenfeld et al. 2012). Ahrens (2012) showed that earthquakes can cause strong waves on the lakes.

\section{d. Astronomical indicators}

The findings show that stars, sun, and moon are important indicators (Tables 6 and 8). Literature shows that astronomical indicators are widely used in Peru and Bolivia (Orlove et al. 2000), Australia (Green et al. 2010), New Zealand (King et al. 2008), Burkina Faso (Roncoli et al. 2002), Kenya (Luseno et al. 2003; Ifejika Speranza et al. 2010), Botswana (Kolawole et al. 2014), Tanzania (Chang'a et al. 2010; Chengula and Nyambo 2016), and Malawi (Kalanda-Joshua et al. 2011).

\section{e. Rainmakers}

The findings reported that rainmakers provide rainfall predictions in the study area. Literature shows that rainmakers are dependable sources of rainfall predictions for Nganyi community in western Kenya, Shona in Zimbabwe, agropastoral communities in the Kalahari Desert in Botswana, smallholders on the slopes of Mount Kilimanjaro, the Bonam community in Burkina Fasa, and Aborigines in Australia (Chengula and Nyambo 2016; Clarke 2009; Guthiga and Newsham 2011; Mogotsi et al. 2011; Onyango 2013; Roncoli et al. 2002; Vijfhuizen, 1997). This is part of the cultural beliefs in many African ethnic groupings.

\section{Conclusions}

The study has established that biotic and abiotic environmental indicators play an important role in helping to provide climate information to farmers in the Rwenzori region. Key informants and literature indicate that the main driver of biotic indicators during the onset and cessation of rains is availability of food resources, and this applies mostly to birds, insects, and fish. The onset and cessation of rain forecasts influence pastoralists' and farmers' decision-making in selection of crop enterprises and livestock management practices for the first and second rainy seasons.

Meteorologists and the farming community consider similar indicators such as clouds and winds. IF is in agreement with scientific forecasts and not at odds with it. Literature and key informants have shown that that there is a time lag between the observance of biotic indictors and the actual occurrence of onset and cessation of rains. It is interesting to note that pastoralists and farmers use a wide variety of indicators (biotic and 
abiotic), which improves the credibility, saliency, and trustworthiness of the climate predictions. The use of diversity of indicators appears valuable, since it is keenly concerned with plants and animals and provides climate information within the locality.

We have shown that there may, in certain areas, be consistency between what we would expect from scientific forecasts and indigenous forecast indicators that farmers use in estimating the onset and cessation of rains. The fact that the use of abiotic indicators has no noticeable discrepancies as compared with meteorological understanding simply underscores the relevance of the IF indicators. Therefore, national meteorological systems may thus find it valuable to consider biotic indicators as well as the abiotic ones to improve their forecasts and also to better connect their forecasts with the indigenous understanding of rainfall patterns.

There has been a delay by meteorologists in integrating IF in national meteorology systems due to failure to appreciate the phenological explanations of biotic indicators, which provide sound scientific basis for farmers' observations. It should be appreciated that farmers' observations of abiotic indicators concur with meteorological science. This calls for integrations of IF in national meteorological systems in a bid to improve the use of climate information in rural climate change adaptation interventions, and thereby improve rural livelihoods that are dependent on rain-fed agriculture. As African governments increase investments in meteorological infrastructure in rural areas with automatic weather stations, coproduction of climate forecasts by meteorologists and rural populations can be explored. This would entail having participatory meteorological dialogues between meteorologists and farming communities to evaluate the forecasts of the previous season and create consensus on the predictions of the coming season. Coproduction of climate services involves participatory approaches in production and dissemination of climate information between producers and end users.

Acknowledgments. The authors are grateful for support during this research from research assistants and the respondents who made this research a reality through their favorable cooperation. This research did not receive any specific grant from funding agencies in the public, commercial, or not-for-profit sectors. This research was self-financed by the lead author for data collection, and special thanks are given to Nassali Mercy Nkuba for moral support. We are grateful to Kabarole Research and Resource Centre for their collaboration during the field work and the government of Uganda for permission to carry out the study. We appreciate the insights from Mujuni Godfrey, Prof. Madibela, Prof. Adedoyin, Prof.
Moseki, Prof. Kenabatho, Prof. Allotey, Kabi Samuel, Dr. Bogoza Patrick, Prof. Perkins, Dr. AryamanyaMugisha, Dr. A. G. Batte, Prof. Kehelpannala Wilbert, Dr. Diana Nalwanga, Dr. Kabelo Senyatso, Keddy Molefi, and wildlife officers from the Uganda Wildlife Authority. This research is part of Ph.D. work for Michael Robert Nkuba, who thanks the University of Botswana for waiving tuition costs.

\section{REFERENCES}

Aguado, E., and J. E. Burt, 2010: Understanding Weather and Climate. Pearson, 608 pp.

Ahrens, C. D., 2012: Meteorology Today: An Introduction to Weather, Climate, and the Environment. West Publishing, $592 \mathrm{pp}$.

Aruho, C., R. Basiita, D. Kahwa, G. Bwanika, and J. Rutaisire, 2013: Reproductive biology of Bagrus docmak in the Victoria Nile, Uganda. Afr. J. Aquat. Sci., 38, 263-271, https://doi.org/ 10.2989/16085914.2013.807972.

Bale, J., and S. Hayward, 2010: Insect overwintering in a changing climate. J. Exp. Biol., 213, 980-994, https://doi.org/10.1242/ jeb.037911.

Barry, R. G., and R. J. Chorley, 2009: Atmosphere, Weather and Climate. Routledge, $536 \mathrm{pp}$.

Basalirwa, C., 1995: Delineation of Uganda into climatological rainfall zones using the method of principal component analysis. Int. J. Climatol., 15, 1161-1177, https://doi.org/10.1002/ joc. 3370151008 .

Batte, A. G., G. Rümpker, M. Lindenfeld, and A. Schumann, 2014: Structurally controlled seismic anisotropy above small earthquakes in crustal rocks beneath the Rwenzori region, Albertine Rift, Uganda. J. Afr. Earth Sci., 100, 579-585, https://doi.org/ 10.1016/j.jafrearsci.2014.08.001.

Bendix, J., J. Homeier, E. C. Ortiz, P. Emck, S.-W. Breckle, M. Richter, and E. Beck, 2006: Seasonality of weather and tree phenology in a tropical evergreen mountain rain forest. Int. J. Biometeor., $\mathbf{5 0}$, 370-384, https://doi.org/10.1007/s00484-006-0029-8.

Berkes, F., 1999: Sacred Ecology: Traditional Ecological Knowledge and Management Systems. Taylor and Francis, 209 pp.

Beugnon, G., and A. Déjean, 1992: Adaptative properties of the chemical trail system of the African weaver ant Oecophylla longinoda Latreille (Hymenoptera, Formicidae, Formicinae). Insectes Soc., 39, 341-346, https://doi.org/10.1007/BF01323954.

Bobba, G. A., D. S. Jefferies, W. G. Booty, and V. P. Singh, 1995: Watershed acidification and modelling. Environmental Hydrology, V. P. Singh, Ed., Springer, 1-12.

Broadhead, J., C. Ong, and C. Black, 2003: Tree phenology and water availability in semi-arid agroforestry systems. For. Ecol. Manage., 180 (1-3), 61-73, https://doi.org/10.1016/S0378-1127(02)00602-3.

Brown, L. H., E. K. Urban, and K. Newman, 1982: The Birds of Africa. Vol. I, Academic Press, $521 \mathrm{pp}$.

Chang'a, L. B., P. Z. Yanda, and J. Ngana, 2010: Indigenous knowledge in seasonal rainfall prediction in Tanzania: A case of the south-western highland of Tanzania. J. Geogr. Reg. Plann., 3 (4), 66-72.

Chapman, C. A., L. J. Chapman, T. T. Struhsaker, A. E. Zanne, C. J. Clark, and J. R. Poulsen, 2005: A long-term evaluation of fruiting phenology: Importance of climate change. J. Trop. Ecol., 21, 31-45, https://doi.org/10.1017/S0266467404001993.

Chengula, F., and B. Nyambo, 2016: The significance of indigenous weather forecast knowledge and practices under weather 
variability and climate change: A case study of smallholder farmers on the slopes of Mount Kilimanjaro. Int. J. Agric. Educ. Ext., 2, 31-43.

Clarke, P. A., 2009: Australian Aboriginal ethnometeorology and seasonal calendars. Hist. Anthropol., 20, 79-106.

Cochran, W. G., 1963: Sampling Technique. 2nd ed. John Wiley and Sons, $413 \mathrm{pp}$.

Cortés-Flores, J., G. Cornejo-Tenorio, and G. Ibarra-Manríquez, 2015: Flowering phenology and pollination syndromes in species with different growth forms in a neotropical temperate forest of Mexico. Botany, 93, 361-367, https://doi.org/10.1139/cjb-2014-0218.

Dadebo, E., D. Aemro, and Y. Tekle-Giorgis, 2014: Food and feeding habits of the African catfish Clarias gariepinus (Burchell, 1822) (Pisces: Clariidae) in Lake Koka, Ethiopia. Afr. J. Ecol., 52, 471-478, https://doi.org/10.1111/aje.12146.

Davie, T., 2008: Fundamentals of Hydrology. Taylor and Francis, $220 \mathrm{pp}$.

Elzinga, R. J., 1987: Fundamentals of Entomology. Prentice-Hall, $456 \mathrm{pp}$.

Fand, B. B., A. L. Kamble, and M. Kumar, 2012: Will climate change pose serious threat to crop pest management: A critical review. Int. J. Sci. Res. Publ., 211, 1-14.

Fry, C. H., and R. M. Harwin, 1988: Caprimulgidae: Nightjars. The Birds of Africa, C. H. Fry, S. Keith, and E. K. Urban, Eds., Vol. III, Academic Press, 155-196.

— S. Keith, and E. K. Urban, Eds., 1992a: The Birds of Africa. Vol. IV, Academic Press, 632 pp.

, and $-1992 b$ : Hirundinidae: Swallows and martins. The Birds of Africa, C. H. Fry, S. Keith, and E. K. Urban, Eds., Vol. IV, Academic Press, 125-196.

- — , and — Eds., 2000: The Birds of Africa. Vol. VI, Academic Press, 600 pp.

—, — , and — 2004: The Birds of Africa. Vol. VII, Academic Press, 728 pp.

Galacgac, E. S., and C. M. Balisacan, 2009: Traditional weather forecasting for sustainable agroforestry practices in Ilocos Norte Province, Philippines. For. Ecol. Manage., 257, 2044 2053, https://doi.org/10.1016/j.foreco.2009.01.002.

Galloway-McLean, K., 2010: Advance Guard: Climate Change Impacts, Adaptation, Mitigation and Indigenous Peoples. United Nations University Traditional Knowledge Initiative, 128 pp.

Gearheard, S., M. Pocernich, R. Stewart, J. Sanguya, and H. P. Huntington, 2010: Linking Inuit knowledge and meteorological station observations to understand changing wind patterns at Clyde River, Nunavut. Climatic Change, 100, 267-294, https://doi.org/10.1007/s10584-009-9587-1.

Gómez-Baggethun, E., V. Reyes-García, P. Olsson, and C. Montes, 2012: Traditional ecological knowledge and community resilience to environmental extremes: A case study in Donana, SW Spain. Global Environ. Change, 22, 640-650, https://doi.org/ 10.1016/j.gloenvcha.2012.02.005.

Grant, P. R., B. R. Grant, L. F. Keller, and K. Petren, 2000: Effects of El Niño events on Darwin's finch productivity. Ecology, 81, 2442-2457, https://doi.org/10.2307/177466.

Green, D., J. Billy, and A. Tapim, 2010: Indigenous Australians' knowledge of weather and climate. Climatic Change, 100, 337354, https://doi.org/10.1007/s10584-010-9803-z.

Guthiga, P., and A. Newsham, 2011: Meteorologists meeting rainmakers: Indigenous knowledge and climate policy processes in Kenya. IDS Bull., 42, 104-109, https://doi.org/ 10.1111/j.1759-5436.2011.00228.x.

Gyampoh, B. A., and W. A. Asante, 2011: Mapping and documenting indigenous knowledge in climate change adaptation in Ghana. United Nations Development Programme Tech. Rep., 139 pp.

Hockings, K. J., J. R. Anderson, and T. Matsuzawa, 2009: Use of wild and cultivated foods by chimpanzees at Bossou, Republic of Guinea: Feeding dynamics in a human-influenced environment. Amer. J. Primatol., 7, 636-646, https://doi.org/10.1002/ajp.20698.

Hoegh-Guldberg, O., and Coauthors, 2018: Impacts of $1.5^{\circ} \mathrm{C}$ global warming on natural and human systems. Global Warming of $1.5^{\circ} \mathrm{C}$, V. Masson-Delmotte et al., Eds., Cambridge University Press, 175-311, https://www.ipcc.ch/site/assets/uploads/sites/2/ 2019/06/SR15_Chapter3_Low_Res.pdf.

Hold $\varnothing$, R. M., J. P. Dudley, and L. R. McDowell, 2002: Geophagy in the African elephant in relation to availability of dietary sodium. J. Mammal., 83, 652-664, https://doi.org/10.1644/ 1545-1542(2002)083<0652:GITAEI $>2.0$.CO;2.

Hulme, M. F., and Coauthors, 2013: Conserving the birds of Uganda's banana-coffee arc: Land sparing and land sharing compared. PLOS ONE, 8, e54597, https://doi.org/10.1371/journal.pone.0054597.

Husen, S., C. Bachmann, and D. Giardini, 2007: Locally triggered seismicity in the central Swiss Alps following the large rainfall event of August 2005. Geophys. J. Int., 171, 1126-1134, https:// doi.org/10.1111/j.1365-246X.2007.03561.x.

Ifejika Speranza, C., B. Kiteme, P. Ambenje, U. Wiesmann, and S. Makali, 2010: Indigenous knowledge related to climate variability and change: Insights from droughts in semi-arid areas of former Makueni District, Kenya. Climatic Change, 100, 295-315, https://doi.org/10.1007/s10584-009-9713-0.

Irwin, M. P. S., 1986: Cuculidae: Cuckoos, malkohas and coucals. The Birds of Africa, C. H. Fry, S. Keith, and E. K. Urban, Eds., Vol. III, Academic Press, 58-104.

Jiménez, M.-J., and M. García-Fernández, 2000: Occurrence of shallow earthquakes following periods of intense rainfall in Tenerife, Canary Islands. J. Volcanol. Geotherm. Res., 103, 463-468, https://doi.org/10.1016/S0377-0273(00)00237-7.

Kalanda-Joshua, M., C. Ngongondo, L. Chipeta, and F. Mpembeka, 2011: Integrating indigenous knowledge with conventional science: Enhancing localised climate and weather forecasts in Nessa, Mulanje, Malawi. Phys. Chem. Earth, 36, 996-1003, https://doi.org/10.1016/j.pce.2011.08.001.

Kangwagye, T., 1974: The seasonal incidence of biting flies (Diptera) in Rwenzori National park and Kigezi Game reserve, Uganda. Bull. Entomol. Res., 63, 535-549, https:// doi.org/10.1017/S0007485300047775.

King, D. N. T., A. Skipper, and W. B. Tawhai, 2008: Māori environmental knowledge of local weather and climate change in Aotearoa-New Zealand. Climatic Change, 90, 385-409, https://doi.org/10.1007/s10584-007-9372-y.

Kolawole, O. D., P. Wolski, B. Ngwenya, and G. Mmopelwa, 2014: Ethno-meteorology and scientific weather forecasting: Small farmers and scientists' perspectives on climate variability in the Okavango Delta, Botswana. Climate Risk Manage., 4-5, 43-58, https://doi.org/10.1016/j.crm.2014.08.002.

Kraft, T., J. Wassermann, E. Schmedes, and H. Igel, 2006: Meteorological triggering of earthquake swarms at Mt. Hochstaufen, SE-Germany. Tectonophysics, 424 (3-4), 245-258, https://doi.org/10.1016/j.tecto.2006.03.044.

Kushwaha, C., S. Tripathi, B. Tripathi, and K. Singh, 2011: Patterns of tree phenological diversity in dry tropics. Acta Ecol. Sin., 31, 179-185, https://doi.org/10.1016/j.chnaes.2011.04.003.

Lefale, P. F., 2010: Ua 'afa le Aso Stormy weather today: Traditional ecological knowledge of weather and climate. The Samoa experience. Climatic Change, 100, 317-335, https:// doi.org/10.1007/s10584-009-9722-z. 
Leonard, S., M. Parsons, K. Olawsky, and F. Kofod, 2013: The role of culture and traditional knowledge in climate change adaptation: Insights from East Kimberley, Australia. Global Environ. Change, 23, 623-632, https://doi.org/10.1016/j.gloenvcha.2013.02.012.

Leroux, M., 2001: The Meteorology and Climate of Tropical Africa. Springer Science and Business Media, $548 \mathrm{pp}$.

Lindenfeld, M., and G. Rümpker, 2011: Detection of mantle earthquakes beneath the East African Rift. Geophys. J. Int., 186, 1-5, https://doi.org/10.1111/j.1365-246X.2011.05048.x.

,,,- K. Link, D. Koehn, and A. Batte, 2012: Fluid-triggered earthquake swarms in the Rwenzori region, East African Rift-Evidence for rift initiation. Tectonophysics, 566-567, 95-104, https://doi.org/10.1016/j.tecto.2012.07.010.

Luseno, W. K., J. G. McPeak, C. B. Barrett, P. D. Little, and G. Gebru, 2003: Assessing the value of climate forecast information for pastoralists: Evidence from southern Ethiopia and northern Kenya. World Dev., 31, 1477-1494, https:// doi.org/10.1016/S0305-750X(03)00113-x.

Lutgens, F. K., E. J. Tarbuck, and D. Tusa, 2001: The Atmosphere: An Introduction to Meteorology. Prentice-Hall, $484 \mathrm{pp}$.

Maiga, I., M. Lecoq, and S. Morand, 2010: Egg survival strategies of the Senegalese grasshopper during the dry season in the African Sahel. Int. J. Pest Manage., 56, 223-232, https:// doi.org/10.1080/09670870903464390.

Marin, A., 2010: Riders under storms: Contributions of nomadic herders' observations to analysing climate change in Mongolia. Global Environ. Change, 20, 162-176, https:// doi.org/10.1016/j.gloenvcha.2009.10.004.

Mogotsi, K., A. Moroka, O. Sitang, and R. Chibua, 2011: Seasonal precipitation forecasts: Agro-ecological knowledge among rural Kalahari communities. Afr. J. Agric. Res., 6, 916-922.

Morel, G. J., M. Y. Morel, and C. H. Fry, 1986: Columbidae: Pigeons and doves. The Birds of Africa, C. H. Fry, S. Keith, and E. K. Urban, Eds., Vol. II, Academic Press, 442-498.

Moscovice, L., M. Issa, K. Petrzelkova, N. Keuler, C. Snowdon, and M. Huffman, 2007: Fruit availability, chimpanzee diet, and grouping patterns on Rubondo Island, Tanzania. Amer. J. Primatol., 69, 487-502, https://doi.org/10.1002/ ajp.20350.

Motsumi, S., L. Magole, and D. Kgathi, 2012: Indigenous knowledge and land use policy: Implications for livelihoods of flood recession farming communities in the Okavango Delta, Botswana. Phys. Chem. Earth, 50-52, 185-195, https:// doi.org/10.1016/j.pce.2012.09.013.

Mpandeli, S., and P. Maponya, 2013: The use of climate forecasts information by farmers in Limpopo Province, South Africa. J. Agric. Sci., 5, 47-55, https://doi.org/10.5539/JAS.V5N2P47.

Mugalavai, E. M., E. C. Kipkorir, D. Raes, and M. S. Rao, 2008: Analysis of rainfall onset, cessation and length of growing season for western Kenya. Agric. For. Meteor., 148, 1123-1135, https://doi.org/10.1016/j.agrformet.2008.02.013.

Mwebaza-Ndawula, L., 1984: Food and feeding habits of Clarias mossambicus from four areas in the Lake Victoria basin, East Africa. Environ. Biol. Fishes, 10 (1-2), 69-76, https://doi.org/ 10.1007/BF00001663.

Naughton-Treves, L., 1998: Predicting patterns of crop damage by wildlife around Kibale National Park, Uganda. Conserv. Biol., 12, 156-168, https://doi.org/10.1046/j.1523-1739.1998.96346.x.

Newman, K., 1982: Anatidae: Swans, geese and ducks. The Birds of Africa, L. H. Brown, E. K. Urban, and K. Newman, Eds., Vol. I, Academic Press, 220-293.

Nganzi, P., T. C. Kajumba, M. Barihaihi, J. Bataze, and G. Mujuni, 2015: Use of indigenous knowledge in weather forecasting in Uganda: National survey. Uganda National Meteorology Authority Doc., 70 pp.

Nkomwa, E. C., J. M. Kalanda, C. Ngongondo, M. Monjerezi, and F. Chipungu, 2014: Assessing indigenous knowledge systems and climate change adaptation strategies in agriculture: A case study of Chagaka Village, Chikhwawa, southern Malawi. Phys. Chem. Earth, 67, 164-172, https://doi.org/10.1016/j.pce.2013.10.002.

Nkuba, M., R. Chanda, G. Mmopelwa, A. Adedoyin, M. N. Mangheni, D. Lesolle, and E. Kato, 2019a: Do indigenous forecasts and scientific forecasts influence arable farmers' and agro-pastoralists' estimation of onset and cessation of rains? Empirical evidence from Rwenzori region, Western Uganda. Agric. For. Meteor., 278, 107667, https://doi.org/10.1016/j.agrformet.2019.107667.

,,,--- E. Kato, M. N. Mangheni, and D. Lesolle, 2019b: The effect of climate information in pastoralists' adaptation to climate change. Int. J. Climate Change Strategies Manage., 11, 442-464, https://doi.org/10.1108/IJCCSM-10-2018-0073.

Novotny, V., and Y. Basset, 1998: Seasonality of sap-sucking insects (Auchenorrhyncha, Hemiptera) feeding on Ficus (Moraceae) in a lowland rain forest in New Guinea. Oecologia, 115, 514-522, https://doi.org/10.1007/s004420050549.

Ochumba, P. B. O., and J. O. M. Ala, 1992: Distribution of fishes along the Sondu-Miriu River of Lake Victoria, Kenya with special reference to upstream migration, biology and yield. Aquacult. Res., 23, 701-719, https://doi.org/10.1111/j.13652109.1992.tb00813.x.

Ogallo, L. J., 1989: The spatial and temporal patterns of the East African seasonal rainfall derived from principal component analysis. Int. J. Climatol., 9, 145-167, https://doi.org/10.1002/ joc.3370090204.

, and J. E. Janowiak, and M. S. Halpert, 1988: Teleconnection between seasonal rainfall over East Africa and global sea surface temperature anomalies. J. Meteor. Soc. Japan, 66, 807822, https://doi.org/10.2151/JMSJ1965.66.6_807.

Okonya, J. S., and J. Kroschel, 2013: Indigenous knowledge of seasonal weather forecasting: A case study in six regions of Uganda. Agric. Sci., 4, 641-648, https://doi.org/10.4236/AS.2013.412086.

Onyango, M., 2013: Integrating indigenous knowledge for community adaptation to climate change: Case of Nganyi community of western Kenya. Int. J. Curr. Trends Res., 2, 345-357.

Orlove, B. S., J. C. Chiang, and M. A. Cane, 2000: Forecasting Andean rainfall and crop yield from the influence of El Niño on Pleiades visibility. Nature, 403, 68-71, https://doi.org/ $10.1038 / 47456$

, C. Roncoli, M. Kabugo, and A. Majugu, 2010: Indigenous climate knowledge in southern Uganda: The multiple components of a dynamic regional system. Climatic Change, 100, 243-265, https://doi.org/10.1007/s10584-009-9586-2.

Parr, H., 1959: Studies on Stomoxys calcitrans (L.) in Uganda, East Africa.: I.-A method of rearing large numbers of Stomoxys calcitrans. Bull. Entomol. Res., 50, 165-169, https://doi.org/ 10.1017/S0007485300054481.

Pearce-Higgins, J. W., R. E. Green, and R. Green, 2014: Birds and Climate Change: Impacts and Conservation Responses. Cambridge University Press, $467 \mathrm{pp}$.

Rao, K. P. C., W. G. Ndegwa, K. Kizito, and A. Oyoo, 2011: Climate variability and change: Farmer perceptions and understanding of intra-seasonal variability in rainfall and associated risk in semi-arid Kenya. Exp. Agric., 47, 267-291, https://doi.org/10.1017/s0014479710000918.

Rode, K. D., P. I. Chiyo, C. A. Chapman, and L. R. McDowell, 2006: Nutritional ecology of elephants in Kibale National Park, Uganda, and its relationship with crop-raiding 
behaviour. J. Trop. Ecol., 22, 441-449, https://doi.org/ 10.1017/s0266467406003233.

Roncoli, C., K. Ingram, and P. Kirshen, 2002: Reading the rains: Local knowledge and rainfall forecasting in Burkina Faso. Soc. Nat. Resour., 15, 409-427, https://doi.org/10.1080/ 08941920252866774

_- , and Coauthors, 2008: From accessing to assessing forecasts: An end-to-end study of participatory climate forecast dissemination in Burkina Faso (West Africa). Climatic Change, 92, 433-460, https://doi.org/10.1007/s10584-0089445-6.

Rothman, J. M., C. A. Chapman, T. T. Struhsaker, D. Raubenheimer, D. Twinomugisha, and P. G. Waterman, 2015: Long-term declines in nutritional quality of tropical leaves. Ecology, 96, 873878, https://doi.org/10.1890/14-0391.1.

Roy, J., and Coauthors, 2018: Sustainable development, poverty eradication and reducing inequalities. Global Warming of $1.5^{\circ} \mathrm{C}$, V. Masson-Delmotte et al., Eds., Cambridge University Press, 445-538, https://www.ipcc.ch/site/assets/uploads/sites/2/ 2019/02/SR15_Chapter5_Low_Res.pdf.

Saenz, D., L. A. Fitzgerald, K. A. Baum, and R. N. Conner, 2006: Abiotic correlates of anuran calling phenology: The importance of rain, temperature, and season. Herpetol. Monogr., 20, 64-82, https://doi.org/10.1655/0733-1347(2007)20[64: $\mathrm{ACOACP}] 2.0 . \mathrm{CO} ; 2$.

Schulte, L. M., and S. Lötters, 2013: The power of the seasons: Rainfall triggers parental care in poison frogs. Evol. Ecol., 27, 711-723, https://doi.org/10.1007/s10682-013-9637-z.

Sekhwela, M., and D. Yates, 2007: A phenological study of dominant acacia tree species in areas with different rainfall regimes in the Kalahari of Botswana. J. Arid Environ., 70, 1-17, https:// doi.org/10.1016/j.jaridenv.2006.12.006.

Shaw, E. M., K. J. Beven, N. A. Chappell, and R. Lamb, 2010: Hydrology in Practice. CRC Press, 546 pp.

Singh, K., and C. Kushwaha, 2005: Emerging paradigms of tree phenology in dry tropics. Curr. Sci., 89, 964-975.

, and - 2006: Diversity of flowering and fruiting phenology of trees in a tropical deciduous forest in India. Ann. Bot., 97, 265-276, https://doi.org/10.1093/aob/mcj028.
Slegers, M. F. W., 2008: “If only it would rain”: Farmers' perceptions of rainfall and drought in semiarid central Tanzania. J. Arid Environ., 72, 2106-2123, https://doi.org/10.1016/ j.jaridenv.2008.06.011.

Tweheyo, M., C. M. Hill, and J. Obua, 2005: Patterns of crop raiding by primates around the Budongo Forest Reserve, Uganda. Wildl. Biol., 11 (3), 237-247, https://doi.org/10.2981/ 0909-6396(2005)11[237:POCRBP]2.0.CO;2.

Urban, E. K., 1982: Ardeidae: Herons, egrets and bitterns. The Birds of Africa, L. H. Brown, E. K. Urban, and K. Newman, Eds., Vol. I, Academic Press, 132-168.

Vijfhuizen, C., 1997: Rain-making, political conflicts and gender images: A case from Mutema chieftaincy in Zimbabwe. Zambezia, 24, 31-49.

Visser, M. E., L. te Marvelde, and M. E. Lof, 2012: Adaptive phenological mismatches of birds and their food in a warming world. J. Ornithol., 153, 75-84, https://doi.org/10.1007/ s10336-011-0770-6.

Weatherhead, E., S. Gearheard, and R. G. Barry, 2010: Changes in weather persistence: Insight from Inuit knowledge. Global Environ. Change, 20, 523-528, https://doi.org/ 10.1016/j.gloenvcha.2010.02.002.

Wolda, H., 1978: Seasonal fluctuations in rainfall, food and abundance of tropical insects. J. Anim. Ecol., 47, 369-381, https:// doi.org/10.2307/3789.

Yamakoshi, G., 1998: Dietary responses to fruit scarcity of wild chimpanzees at Bossou, Guinea: Possible implications for ecological importance of tool use. Amer. J. Phys. Anthropol., 106, 283-295, https://doi.org/10.1002/(SICI)1096-8644199807) 106:3<283::AID-AJPA2>3.0.CO;2-O.

Yatuha, J., J. Kang'ombe, and L. Chapman, 2013: Diet and feeding habits of the small catfish, Clarias liocephalus in wetlands of Western Uganda. Afr. J. Ecol., 51, 385-392, https://doi.org/ 10.1111/aje.12048.

Zuma-Netshiukhwi, G., K. Stigter, and S. Walker, 2013: Use of traditional weather/climate knowledge by farmers in the SouthWestern Free State of South Africa: Agrometeorological learning by scientists. Atmosphere, 4, 383-410, https://doi.org/ 10.3390/atmos4040383. 